\title{
The Preparation of Green Banana Flour ${ }^{1}$
}

\author{
Edelmiro J.Rodríguez-Sosa, Miguel A. González, Isabel B. de Caloni, \\ and Orlando Parsi-Ros ${ }^{2}$
}

\begin{abstract}
A green banana flour of good characteristics was prepared using a cabinet dryer. The green bananas were dehydrated as small cubes.

For some tests the dry bulb temperature was set at $160^{\circ} \mathrm{F}\left(71.1^{\circ} \mathrm{C}\right)$ for the first hour and changed to $200^{\circ} \mathrm{F}\left(93.3^{\circ} \mathrm{C}\right)$ for the next $5 \mathrm{~h}$, and for other tests set at $200^{\circ} \mathrm{F}$ the whole period. The average wet bulb depression was $42^{\circ} \mathrm{F}\left(23.3^{\circ} \mathrm{C}\right)$. The metal-mesh trays were filled at different levels. At lower filling levels the dehydration rate was faster. Within the same tray filling level, initial moisture content of green banana cubes was more determinant of the dehydrating rate than were the levels of temperature used. Cupcakes of high acceptability were prepared by mixing equal amounts of green banana flour and wheat flour.
\end{abstract}

\section{INTRODUCTION}

Bananas are intensively cultivated in Puerto Rico. The fruit harvested is mainly the Montecristo cultivar (Cavendish sub-group of Eumusa) which is grown traditionally in the central highlands, especially on the coffee farms. On those farms bananas are planted as secondary cash crops which, at the same time, provide shade for the coffee trees.

Preliminary data for the fiscal year 1974-75 indicated that 744 million bananas were harvested in that period with a cash value of $\$ 6.4$ million. The farm price was $\$ 8.60 /$ thousand. The whole production was consumed locally, yearly per capita consumption being $75 \mathrm{lb}$.

In Puerto Rico bananas are consumed either as a fresh fruit when ripe or as a vegetable when unripe. When eaten green, they are boiled in salted water.

For many years, ripe bananas have been dehydrated for preservation in the tropics. Von Loescke (9) points out that bananas (ripe) have been sun-dried, drum-dried, spray-dried, and dried in cabinet dehydrators. Of these, drum-drying banana flakes seems most promising from the commercial standpoint.

Brekke and Allen (2), using air-blast drying, drum drying, and freeze drying, dehydrated ripe bananas. Blanching of bananas prior to drum drying was found to improve the product, and the addition of $\mathrm{SO}_{2}$ improved its color (7). Mao (5) also studied the drum drying of ripe

' Manuscript submitted to Editorial Board October 20, 1976.

2 Associate Food Technologist, Chemical Engineer and Director, and Assistant Food Technologists, respectively, Food Technology Laboratory, Agricultural Experiment Station, Mayagüez Campus, University of Puerto Rico, Río Piedras, P.R. 
bananas and the distribution and characteristics of amylase in bananas. The osmotic dehydration of ripe bananas was studied by Jackson and Mohamed (4) and by Hope and Vitale (3).

Baked goods traditionally are prepared using cereal flours such as wheat or rye. However, production of flour from staples grown in tropical countries as substitutes, partially or completely, for cereal flours in baked goods, is being encouraged. Among these staples are the farinaceous crops, which are extensively cultivated in most developing countries. Economic as well as nutritional benefits can be derived from these substitutions.

The work reported herein was conducted for the purpose of developing a method for preparing a good quality green banana flour and to evaluate its consumer acceptability.

\section{MATERIALS AND METHODS}

Commercial samples of green bananas were used during the course of this study. The green bananas were steam-peeled in a retort using a pressure of $80 \mathrm{lb} / \mathrm{in}^{2}\left(5.6 \mathrm{~kg} / \mathrm{cm}^{2}\right)$ (2). This treatment loosens the peel from the pulp, making easier its removal by hand. After peeling, bananas were diced with a cutting machine into cubes of about $1 / 2 \times 3 / 8$ $\times 1 / 4$ in $(1.27 \times .95 \times .64 \mathrm{~cm})$. The cubes were soaked for $4 \mathrm{~min}$ in a $1000 \mathrm{p} / \mathrm{m}$ potassium metabisulfite solution, which was previously acidified to $\mathrm{pH} 3.3$ using citric acid.

The treated green banana cubes were dehydrated for $6 \mathrm{~h}$ in a cabinet dryer, using a cross air circulation with the air draft adjusted to 0.1 in $(0.25 \mathrm{~cm})$. The metal-mesh trays used to hold the green banana cubes were filled as follows:

Test A-Trays filled with a single layer of cubes weighing 6 1/2 lb $(2.95$ $\mathrm{kg}$ ) representing a tray load of $1.86 \mathrm{lb} / \mathrm{ft}^{2}\left(.9 \mathrm{~g} / \mathrm{cm}^{2}\right)$. The dry bulb temperature was set at $160^{\circ} \mathrm{F}\left(71.1^{\circ} \mathrm{C}\right)$, and after the first hour, it was increased to $200^{\circ} \mathrm{F}\left(93.3^{\circ} \mathrm{C}\right)$ for the remaining $5 \mathrm{~h}$ of the dehydrating time.

Test B-Trays filled as in A, but the dry bulb temperature was set at $200^{\circ} \mathrm{F}$ for the whole dehydrating time.

Test $\mathrm{C}$-Dehydrating conditions as in A but trays half filled, weighing $13 \mathrm{lb}(5.90 \mathrm{~kg})$, representing a tray load of $3.71 \mathrm{lb} / \mathrm{ft}^{2}\left(1.8 \mathrm{~g} / \mathrm{cm}^{2}\right)$.

Test D-Dehydrating conditions as in B and tray load as in C.

Test $\mathrm{E}$-Dehydrating conditions as in A, but trays completely filled, weighing $231 / 2 \mathrm{lb}(10.61 \mathrm{~kg})$, representing a tray load of 6.71 $\mathrm{lb} / \mathrm{ft}^{2}\left(3.3 \mathrm{~g} / \mathrm{cm}^{2}\right)$.

Test F-Dehydrating conditions as in B and tray load as in E.

Samples of green banana cubes from the center of the trays were 
taken periodically for moisture analysis. The analyses were performed using the vacuum-oven method (1).

After the $6 \mathrm{~h}$ dehydrating period the banana cubes were ground in a mill using a 60 -mesh screen. The flour thus obtained was packed in polyethylene bags (Whirl Pak, ${ }^{3}$ Nasco, Fort Atkison, WI, U.S.A.) and stored in corrugated boxes at an average temperature and relative humidity of $79^{\circ} \mathrm{C}$ and $57 \%$, respectively, until sensory evaluated and for the storage study.

Protein, ether extract, ash, fiber, and nitrogen-free soluble extract were determined in the flour essentially as in the AOAC (1).

The green banana flours were also examined for hydration capacity (HC) and bulk density (BD). HC was determined by weighing $2 \mathrm{~g}$ banana flour in a $225 \mathrm{ml}$ centrifuge bottle, adding $50 \mathrm{ml}$ distilled water, and agitating the mixture vigorously. The suspension was allowed to stand except for being agitated at the end of 5 and $10 \mathrm{~min}$. It was then centrifuged for $5 \mathrm{~min}$ at $1000 \times \mathrm{g}$. The supernatant liquid was discarded by inverting the bottle to obtain good drainage. The bottle with the drained sample was then weighed and $\mathrm{HC}$ calculated from the following formula:

$$
\mathrm{HC}=\frac{\text { Weight of bottle }+ \text { sediment }- \text { weight of bottle }}{2.00 \mathrm{~g}}
$$

$\mathrm{BD}$ was calculated by placing $50 \mathrm{~g}$ flour in a $100 \mathrm{ml}$ graduated cylinder. Flour volume was measured before and after rapping the cylinder 50 times on a wooden table (5).

Cupcakes were prepared by mixing equal amounts of green banana flour and wheat flour. These were submitted to sensory evaluation using a 6-point hedonic scale ranging from "like very much" (6 point) to "dislike" ( 1 point). Twenty-five samples were used per test and the evaluations were performed using untrained consumer panelists of different sex, ages, and economic status.

A portion of the prepared green-banana flour was saved to study changes in moisture and color during storage. Moisture content analyses were performed using the vacuum-oven method (1). Spectral measurements were taken on alcoholic extracts using a Beckman Spectrophotometer Model DB-G set at $445 \mathrm{~nm}$. The alcoholic extracts were prepared from $25 \mathrm{~g}$ flour and $100 \mathrm{ml}$ alcohol by stirring in a Waring Blendor at moderate speed for 2 min. Color measurements were per-

${ }^{3}$ Trade names are used in this publication solely for the purpose of providing specific information. Mention of a trade name does not constitute a guarantee or warranty of equipment or materials by the Agricultural Experiment Station of the University of Puerto Rico or an endorsement over other equipment or materials not mentioned. 
formed directly on the flour samples with a color Hunter Lab Difference Meter Model D 25. A white standard tile of $\mathrm{L}=92.8, \mathrm{a}=-.5$, and $\mathrm{b}=$ +2.5 was used as reference.

\section{RESULTS AND DISCUSSION}

The proximate composition of green banana flour was as follows: protein, $4.56 \%(6.25 \times \mathrm{N})$; ether extract, $1.75 \%$; ash, $3.37 \%$; fiber, $3.35 \%$; and nitrogen-free soluble extract, $86.77 \%$. The average moisture content of fresh green banana was $70.37 \%$, which increased to an average of $76.30 \%$ in the peeling process.

Processing yields in the preparation of green banana flour were as follows:

$\begin{array}{ccc}\text { Tests } & \begin{array}{c}\text { Peel } \\ \%\end{array} & \begin{array}{c}\text { Flour } \\ \%\end{array} \\ \text { A } & 50.68 & 25.67 \\ \text { B } & 48.22 & 28.19 \\ \text { C } & 48.94 & 23.69 \\ \text { D } & 49.24 & 26.43 \\ \text { E } & 48.63 & 29.34 \\ \text { F } & 54.03 & 26.97\end{array}$

The average peel content of green banana was $49.96 \%$, while the average flour percentage obtained was 26.72 , based on peeled bananas (Range $=5.65$ ). The lowest flour yield percentage was obtained in test $\mathrm{C}$, while the highest was obtained in test D.

The average wet bulb depression while dehydrating the banana cubes was $42^{\circ} \mathrm{F}\left(23.3^{\circ} \mathrm{C}\right)$. Green banana cubes tended to shrink slightly during the dehydrating time. The average measures of cubes prior and after dehydration were $1.45 \times .93 \times .65 \mathrm{~cm}$ and $1.39 \times .78 \times .47 \mathrm{~cm}$ respectively.

Within the same tray filling level, samples with higher initial moisture content dehydrated slower than those of low initial moisture content (fig. 1). Apparently, the difference in temperature in the first hour did not exert a significant influence in the dehydrating behavior of samples. Thus, in trays filled with a single layer of cubes, samples in test B, which had an initial moisture content of $75.15 \%$, dried faster than samples in test $\mathrm{A}$, which had an initial moisture content of $76.18 \%$. Samples in A contained an average of $0.05 \mathrm{lb}$ more water than samples in B. In half-filled trays the initial moisture content of samples in C, which dehydrated faster, was $76.45 \%$, while in D, it was $77.94 \%$. Samples in D contained an average of $1.01 \mathrm{lb}$ more water than samples in C. Finally, in completely filled trays, samples in $\mathrm{F}$ had an average

${ }^{4}$ Based on peeled bananas. 


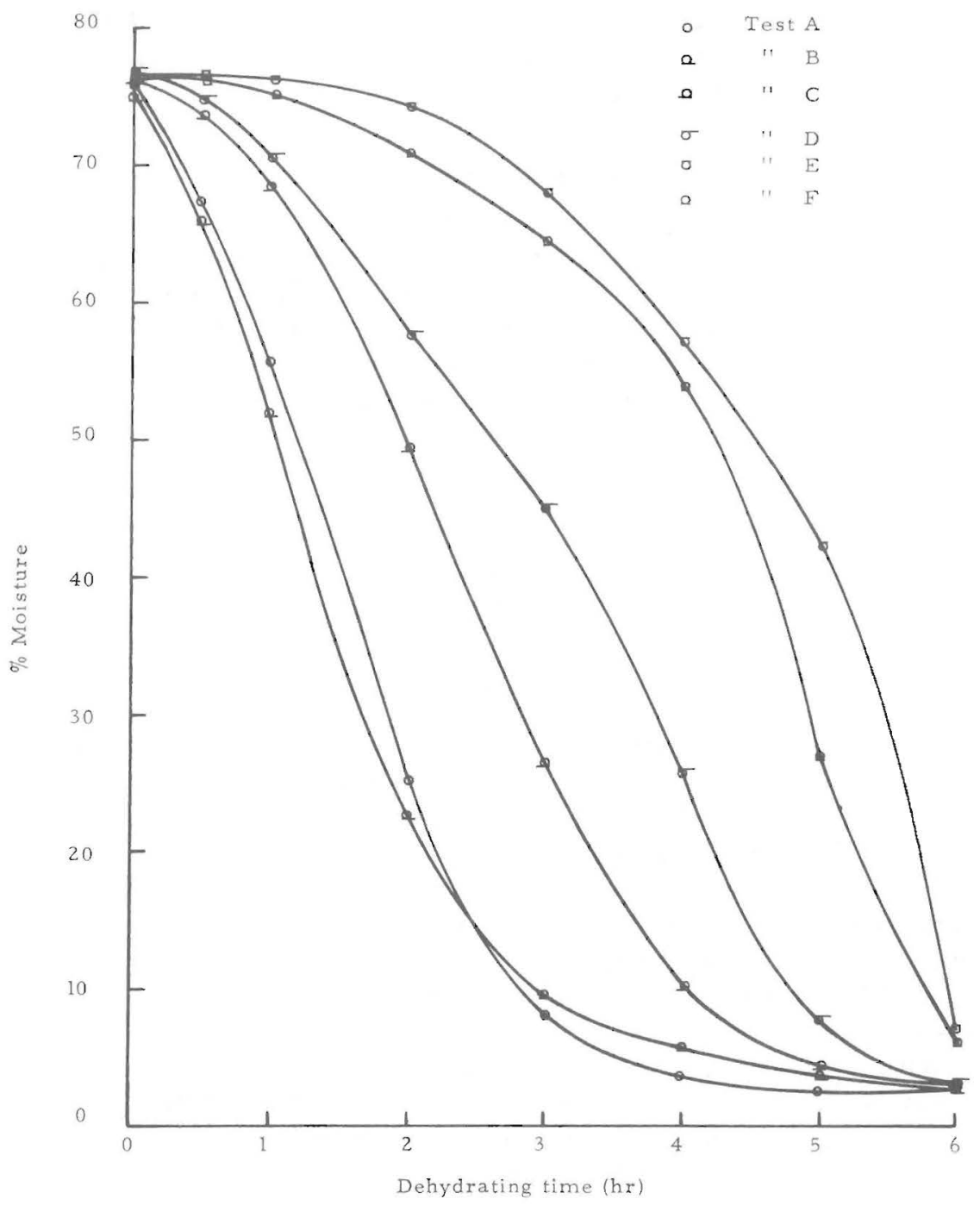

FiG. 1. - Changes in moisture content of green banana cubes during dehydration.

of $0.19 \mathrm{lb}$ less water than samples in $\mathrm{E}$ and dehydrated faster (75.63 and $76.43 \%$ moisture, respectively).

As expected, it was easier to dehydrate the cubes when placed in a single layer in the metal-mesh trays and most difficult when the trays were completely filled (fig. 1). If $10 \%$ moisture content is taken as an adequate level of dehydration $3 \mathrm{~h}$ were enough to dehydrate the cubes when placed in a single layer. However, it took $6 \mathrm{~h}$ to dehydrate the 
TABLE 1. - Changes in color during storage of green banana flour, and the hydration capacity and bulk density at time of preparation

\begin{tabular}{|c|c|c|c|c|c|c|c|c|}
\hline & & \multirow{2}{*}{$\begin{array}{l}\text { Storage } \\
\text { time }\end{array}$} & \multicolumn{6}{|c|}{ Tests } \\
\hline & & & $\mathrm{A}$ & B & $\mathrm{C}$ & D & $\mathrm{E}$ & $\mathrm{F}$ \\
\hline \multirow{5}{*}{\multicolumn{2}{|c|}{$\begin{array}{l}\text { Spectrophotometric } \\
\text { absorbencies }(\mathrm{nm})\end{array}$}} & Weeks & & & & & & \\
\hline & & 2 & 0.400 & 0.620 & 0.483 & 0.608 & 0.835 & 0.707 \\
\hline & & 5 & .343 & .283 & .463 & .323 & .548 & .415 \\
\hline & & 9 & .243 & .145 & .387 & .230 & .454 & .332 \\
\hline & & 13 & .245 & .148 & .316 & .173 & .334 & .294 \\
\hline \multirow{12}{*}{$\begin{array}{l}\text { Color Hunter mea- } \\
\text { surements }\end{array}$} & \multirow[t]{4}{*}{$\mathrm{L}$} & 2 & - & 60.3 & - & 59.9 & 58.1 & 56.9 \\
\hline & & 5 & 61.9 & 60.3 & 60.8 & 58.8 & 57.6 & 57.3 \\
\hline & & 9 & 59.4 & 59.9 & 59.6 & 59.1 & 58.2 & 56.3 \\
\hline & & 13 & 59.4 & 59.0 & 59.5 & 59.5 & 59.1 & 56.0 \\
\hline & \multirow[t]{4}{*}{$-a$} & 2 & - & 1.6 & - & 2.2 & 2.4 & 2.1 \\
\hline & & 5 & .9 & .6 & 1.5 & 1.2 & 1.6 & 1.0 \\
\hline & & 9 & .2 & .3 & 1.1 & 1.2 & 1.3 & .8 \\
\hline & & 13 & .1 & .2 & 1.3 & .9 & 1.6 & 1.1 \\
\hline & \multirow[t]{4}{*}{$+b$} & 2 & - & 12.0 & - & 13.0 & 16.0 & 14.2 \\
\hline & & 5 & 10.1 & 9.2 & 10.6 & 9.8 & 13.8 & 13.3 \\
\hline & & 9 & 8.1 & 7.4 & 9.5 & 8.6 & 12.5 & 11.0 \\
\hline & & 13 & 8.7 & 7.2 & 9.6 & 7.8 & 11.9 & 10.9 \\
\hline Hydration capacity (g/2g) & & & 6.02 & 5.80 & 6.73 & 6.01 & 5.89 & 5.81 \\
\hline Bulk density $(\mathrm{g} / \mathrm{ml})$ & & & .8065 & .7864 & .8154 & .8040 & .7897 & .7566 \\
\hline
\end{tabular}


cubes in trays completely filled. In half-filled trays it took between 4 and $5 \mathrm{~h}$.

In $\mathrm{E}$ and $\mathrm{F}$, with metal-mesh trays completely filled, the dehydrating rate was very slow at the earlier stages, mainly because of the difficulty of hot air in passing and water escaping through the successive layers of banana cubes. However, as dehydration progressed, the rate became faster. At the later stages the shrinkage of banana cubes reduced their volume, increasing air spaces and permitting the hot air to pass more easily through the layers of cubes, thus facilitating the removal of water.

The average $\mathrm{HC}$ of samples was $6.04 \mathrm{~g}$ of water per $2 \mathrm{~g}$ of flour and the average $\mathrm{BD}$ was $0.79 \mathrm{~g} / \mathrm{ml}$ (table 1 ). The correlation coefficient between $\mathrm{HC}$ and $\mathrm{BD}$ was 0.89 . The $\mathrm{BD}$ was higher for samples of higher $\mathrm{HC}$.

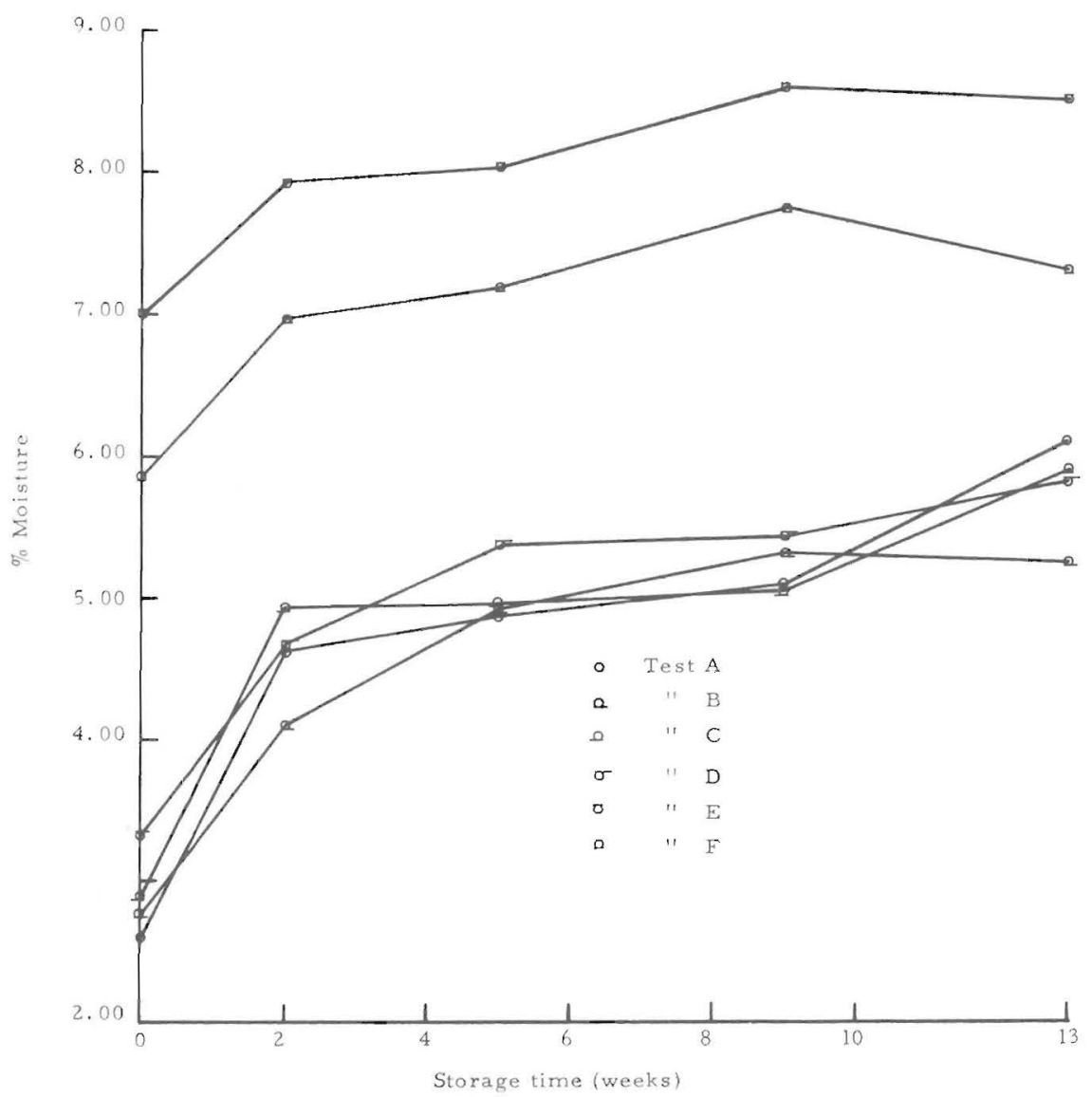

Frg. 2.- Changes in moisture content of green banana flour during storage. 
The cupcakes prepared for sensory evaluations were highly accepted by panelists. The average score obtained was 5.63 ranging from 5.32 to 5.76. The cupcakes had the typical texture and surface color of cupcakes prepared using wheat flour alone. However, the inside color tended to be a greyish color instead of the yellowish one of the wheat cupcakes.

To determine how green banana flour absorbed moisture from the environment, samples of each dehydrating test were stored under conditions similar to those of island supermarkets.

The initial moisture content noted in figure 2 is the moisture measured when samples were taken out of the cabinet dryer. Moisture content, as expected, tended to increase as storage time increased. These increases were higher during the first two weeks.

The absorbency of green banana flour measured at $445 \mathrm{~nm}$ tended to decrease as the storage time increased (table 1). Initial absorbencies were different mainly because of differences in raw material. Absorbencies of the alcoholic extracts of less mature bananas were lower.

The lightness $(L)$, greeness $(-a)$, and yellowness $(+b)$ of banana flours teded to decrease during storage (table 1). As with the absorbencies, initial color of flour was different mainly because of differences in raw material. More mature bananas were higher in yellow component $(+b)$ as well as in absorbency. The correlation coefficient between yellowness (+b) and absorbency was .92 .

In conclusion, green banana flour can be partially substituted for wheat flour in the preparation of cupcakes of good acceptability. The green banana flour can be stored for more than 13 weeks in which the absorbed moisture is less than the moisture in commercial wheat flour, which is around $12 \%$.

\section{RESUMEN}

Se preparó una harina de guineo verde de una calidad aceptable usando un deshidratador de gabinete. Los guineos verdes se pelaron a vapor, se cortaron en cubos pequeños y se pusieron en bandejas para deshidratalos. Se probaron seis formas distintas a base deil espesor de la camada de cubos y de las temperaturas. Los 3 niveles fueron: una sola camada de cubos $\left(6^{1 / 2} \mathrm{lb}\right.$.), dos camadas (hasta la mitad, $13 \mathrm{lb}$.); y cuatro camadas (completamente llenas, $23^{1 / 2} \mathrm{lb}$.). Las temperaturas fueron: $160^{\circ} \mathrm{F}$. (71.1 $1^{\circ}$ C).) por la primera hora de deshidratación subiendo luego a $200^{\circ} \mathrm{F}$. (93.3 ${ }^{\circ} \mathrm{C}$.) el resto del período; y otras a $200^{\circ} \mathrm{F}$. todo el período. El periado de deshidratâción fue de 6 horas. A los niveles más bajos de llenado la deshidratación fue más rápida. La humedad inicial de los cubos de guineo verde fue más determinante de la rapidez de deshidratación que los niveles de temperatura usados dentro de un mismo nivel de llenado. De la harina se prepararon bizcochitos que tuvieron gran aceptación. Éstos se prepararon mezclando cantidades iguales de harina de guineo y harina de trigo.

\section{LITERATURE CITED}

1. Association of Official Agricultural Chemists, Official methods of analyses, 11th ed, Washington, D.C. 1970. 
2. Brekke, J. E., and Allen, L., Dehydrated bananas, Food Technol., 21(10): 1391-5, 1967.

3. Hope, G. W., and Vitale, D. G., International Development Research Centre Monographs, Canada Dept. Agric., Food Res. Inst., Ottawa, Ontario, IDRC-004e, 1972.

4. Jackson, T. H., and Mohamed, B. B., The Shambat Process. New development arising from the osmotic dehydration of fruits and vegetables, Sudan J. Food Sci. and Technol., 3: 18-23, 1971.

5. Mao, W. W., Banana Fruit Technology: I. Dehydration of banana puree by drum drying. II. Properties of amylose in banana, Diss. Abstr. Int., B. 35(8): 3971-2, 1975.

6. Olson, R. L., Harrington, W. O., Neel, G. H., Cole, M. W., and Mullins, W. R., Recent advances, in potato granule technology, Food Technol. 7 (4): 177-81, 1953.

7. Samish, Z., and Coussin, B. R., The production of dehydrated flakes as a means of utilizing surplus bananas, Israel J. Agric. Res.15 (1): 49, 1965.

8. Van Arsdel, W. B., Food Dehydration, Chap. 6. The AVI Publishing Co., Inc., Westport, Conn. U.S.A., 1963.

9. Von Loesecke, H. W., Drying and dehydration of foods, Reinhold Publishing Co., N.Y., 1955. 